\title{
TOWARD A BANK SHAREHOLDER-ORIENTATED MODEL: USING DOUBLE LiABILITY TO Mitigate EXCESSIVE RISK-TAKING
}

Richard Ridyard*

\begin{abstract}
The conventional model for corporate governance depends on the rarely articulated assumption that the costs of failure are largely internalised by the firm and so are taken into account when shareholders determine their risk appetite. In this paper I argue that, when applied to banks, this view is mistaken. Banks do not internalise the costs of failure, hence the risk appetite of bank shareholders is socially excessive. I show that shareholder pressure on their management to accept greater risk can help explain the excessive risk-taking of banks. My analysis indicates that recent corporate governance reforms that attempt to tighten the alignment of managerial and shareholder interests cannot be expected to address the problem I identify. To adequately understand what policies should be explored, we must first recognise that excessive risk-taking is also partly a product of the conventional model. I therefore propose a modification to the conventional model: a regime of double liability that is triggered by bank failure. I analyse how this will reduce bank shareholders' risk appetite and make excessive risk-taking less likely. Welfare improvement occurs because of heightened risk awareness and enhanced risk-taking controls, decreasing the likelihood of failure. Finally, examining a range of possible objections, I conclude that they do not provide a good basis for opposing a regime of double liability and the burden is now on proponents to justify the current limited liability regime for bank shareholders.
\end{abstract}

\section{A. INTRODUCTION}

Many believe that companies can enhance social welfare when managers seek to maximise shareholder wealth. ${ }^{1}$ Under this approach, which I label "the shareholder-orientated model," the managers' incentives are aligned with those of the shareholders. The theory behind shareholder primacy drove the model towards attaining the status of orthodoxy. It has since exerted a profound influence on how we think about corporate

\footnotetext{
* LL.B. (Hons.); Bachelor of Civil Law, University of Oxford. Thanks are due to Professor Paul Davies for extremely helpful comments and guidance on earlier drafts. I am also grateful for conversations with Professor John Armour and Dr James Cullen. Any mistakes are, of course, my own.

${ }^{1}$ See, Milton Friedman, The Social Responsibility of Business is to Increase its Profits, N.Y. Times Mag., September 13, 1970. See also, Henry Hansmann and Reinier Kraakman, 'Toward a Single Model of Corporate Law?' in Joseph A McCahery et al (eds), Corporate Governance Regimes: Convergence and Diversity (OUP, 2002) 58.
} 
governance. One result has been the increase in the prevalence of shareholder rights. ${ }^{2}$

Some commentators argue that managerial incentives played a significant role in the risk-taking decisions financial firms made in the years preceding the financial crisis of 2008-2009. ${ }^{3}$ As emphasised by Ben Bernanke, now Chairman of the Federal Reserve, the risk-taking behaviour of banks affects financial and economic fragility. ${ }^{4}$ Therefore, the strength of the legal environment to mitigate excessive risk-taking of banks is a key to the success of the financial system. Most literature addressing excessive bank risk-taking through corporate governance focuses on managerial incentives. ${ }^{5}$ Discussion of the risk appetite of bank shareholders has been relatively neglected. As a first step to make up for this neglect, such analysis is offered in this paper.

In the search of explanations for excessive bank risk-taking, one prominent argument is that the invectives of managers have not been optimally aligned with the interests of shareholders. It is fair to regard this as the conventional account. This account, which has become widely accepted, has prompted legislators and regulators to implement changes

\footnotetext{
${ }^{2}$ As Murphy and Zabojnik note, "The shareholder-rights movement beginning in the late 1980s and the increased ownership of large institutional investors has forced CEOs to lead their companies' investor-relation efforts, communicating directly with shareholders and institutions." Kevin Murphy and Jan Zabojnik, 'Managerial Capital and the Market for CEOs' (2007) Working Paper, 5.

${ }^{3}$ See, Lucian Bebchuk, Alma Cohen and Holger Spamann, 'The Wages of Failure: Executive Compensation at Bear Stearns and Lehman 2000-2008' (2010) 27 Yale Journal of Regulation 257. See also, Paul Krugman, Reform or Bust, New York Times, September 21, 2009 (arguing, "...you can make the case that reforming bankers' compensation is the single best thing we can do to prevent another financial crisis a few years down the road").

${ }^{4}$ See, Ben Bernanke, 'Non Monetary Effects of the Financial Crisis in the Propagation of the Great Depression' (1983) 73(3) American Economic Review 257.

${ }^{5}$ See, Alex Edmans, Xavier Gabaix and Augustin Landier, 'Multiplicative Model of Optimal CEO Incentives in Market Equilibrium' (2009) 22(12) Review of Financial Studies 4881; Steven Kaplan and Joshua Rauh, 'Wall Street and Main Street: What Contributes to the Rise in the Highest Incomes?' (2010) 23(3) Review of Financial Studies 1004 (on the levels of compensation). See also, Paul Greg, Sarah Jewell and Ian Tonks, 'Executive Pay and Performance: Did Bankers' Bonuses Cause the Crisis?' Working Paper (2011); Kevin Murphy and Michael Jensen, 'CEO Bonus Plans: And How To Fix Them' (2011) Harvard Business School NOM Unit Working Paper 12 (on bonuses). See also, Lucian Bebchuk and Jesse Fried, 'Stealth Compensation Via Retirement Benefits' (2004) 1 Berkley Business Law Journal 291; Lisa Goh and Yong Li 'Executive Pensions and Excess Compensation' (2010) Working Paper (on pensions).
} 
in corporate governance aimed at improving pay-setting processes ${ }^{6}$ and better aligning pay arrangements with the interests of shareholders by making performance related pay of the bank managers more risk sensitive. ${ }^{7}$ To avoid excessive incentives for risk-taking, reformers have also placed considerable weight on shareholder engagement. ${ }^{8}$ However, for such a strategy to make sense, it must be assumed that it is managerial pull rather than shareholder push that generates excessive risk-taking.

The rule of limited liability has also attained a status of orthodoxy, with Henry Hansmann listing it as one of the core elements of corporate law the world over. ${ }^{9}$ Under conventional assumptions, limited liability is said to foster high-risk, high-yield activities with a net present value beneficial to social welfare. Any risk inducing incentives are assumed to be the price of securing efficient capital financing for corporations. $^{10}$

This paper concentrates on the excessive risk-taking of banks to challenge these conventional assumptions. Throughout, it is emphasised that banks are different. I make two main contributions. My first contribution seeks to persuade readers that excessive risk-taking is also partly a product of the conventional model. There are, I explain, two steps to this account. The first is an articulation of key factors that incentivise bank shareholders to prefer excessive risk-taking. Among other things, I show that one of the real criticisms of the conventional model when applied to banks is that the costs of failure are not largely internalised by

\footnotetext{
${ }^{6}$ See, for example, (mandatory "say on pay") The Dodd-Frank Wall Street Reform and Consumer Protection Act of 2010, §951, 124 Stat. 1375, 1899 (2010) (codified as Section 14A of the Securities Exchange Act of 1934).

${ }^{7}$ See, for example, 12 U.S.C. § 5221(b)(3)(D)(i) (2009) (requiring that incentive compensation for senior executive officers of TARP recipients be exclusively in longterm restricted common stock.)

${ }^{8}$ See, The Senior Supervisors Group, Risk Management Lessons From the Global Banking Crisis of 2008 (October 2009); The Walker Review: A Review of Corporate Governance in UK Banks and other Financial Industry Entities: Final Recommendations (November 2009); The de Larosiere Group, The High Level Group on Financial Supervision in the EU (25 February 2009) 29.

${ }^{9}$ Henry Hansmann, 'What is Corporate Law' in Reinier Kraakman, John Armour, Paul Davies, Luca Enriques, Henry Hansmann, Gérard Hertig, Klaus Hopt, Hideki Kanda, and Edward Rock (eds) Anatomy of Corporate Law: A Comparative and Functional Approach (2 ${ }^{\text {nd }}$ ed, OUP 2009).

${ }^{10}$ Frank Easterbrook and Daniel Fischel, 'Limited Liability and the Corporation' (1985) 52 University of Chicago Law Review 89.
} 
the bank, they are borne, at least in part, by taxpayers. Consequently, bank shareholders do not take these costs into account when they determine their risk appetite, and so, their appetite for risk may be socially excessive. It follows that a bank which adheres to convention and is run in the interests of its shareholders is not necessarily enhancing social welfare. My second step is to describe the mechanisms through which exposure to shareholder pressure leads managers to take more risk. This account, contrary to convention, positively takes the view that excessive risk-taking is shareholder driven. My analysis ensures we ask, and give priority to, the right question-that is, how can bank shareholders' risk appetite be minimised?

My second contribution is to put forward a modified approach to bank governance, what I term the bank shareholder-orientated model, based on reducing the risk appetite of shareholders. I develop a case for a regime of double liability that is triggered by bank failure. Under this regime, bank shareholders would stand to lose an additional amount up to, but not exceeding, the par value of their stock in the bank. The increase in potential losses for shareholders, I argue below, will make shareholders more risk averse and induce them to enhance risk-taking controls, leading to the expectation of a reduction in excessive risk-taking. To provide support for this thesis, I examine empirical evidence on double liability in the United States from 1863 to 1933 . Double liability then, could be seen as a complimentary addition to corporate governance measures aimed at reducing the excessive risk-taking of banks.

This paper proceeds in three steps. Part B considers further the conventional model of governance, the concerns it seeks to address and its alleged benefits. Against this background, I describe in Part C key factors that incentivise bank shareholders to prefer socially excessive risk. I then introduce shareholder pressure as a separate likely channel of causation of excessive risk- taking. Part D concludes by showing the limitations of current corporate governance reforms for addressing the problem identified. In Part D, I modify the conventional model to include a regime of double liability. I analyse how this will reduce bank shareholders' risk appetite, and, can help mitigate excessive risk-taking. Throughout Part D, I respond to possible objections for double liability.

While the arguments of this paper are highly suggestive, the limitations of the analysis should be noted. The modified approach to corporate governance presented is confined to banks. Its suitability in other 
sectors is left for future work to consider. It also worth stressing that the main focus of the analysis of double liability is on minimising bank shareholders' risk appetite.

\section{B. The Conventional Shareholder-Orientated Model}

Before the flaws of the shareholder-orientated model when applied to banks are explained, and a modified approach is presented, the reasons commentators have sought to rely on to justify the existing model must be brought out in more detail.

\section{The agency problem}

The starting point is to recognise a separation of management and finance, and of ownership and control. This has been rationalised under what has been termed "agency theory". ${ }^{11}$ An agency relationship is a contract under which one person (the principal) engages another (the agent) to perform a service on their behalf, which involves delegating the authority to make decisions. Internal incentives are crucially important because the decisions which managers make depend on them and a principal can design incentives so as to limit the divergences from their interests. The effectiveness of managerial incentives can therefore directly impact firm performance. These incentives are embodied explicitly in employment contracts, and implicitly through the threat of dismissal or effect on reputation. Observable outcomes are used to provide information useful in determining whether managers have performed their job effectively. ${ }^{12}$

\section{Defining shareholder interests: maximising the stock price}

Next, it is useful to establish what shareholders are interested in. ${ }^{13}$ One of the primary interests of shareholders is the maximisation of their claims,

\footnotetext{
${ }^{11}$ See generally: Ronald Coase, 'The Nature of The Firm' (1937) 4(16) Economica 386. See also, Michael C Jensen and William H Meckling, 'Theory of the firm: managerial behaviour, agency costs and ownership structure' (1976) 3 Journal of Financial Economics 305.

${ }^{12}$ Douglas Diamond and Robert Verrecchia, 'Optimal Managerial Contracts and Equilibrium Security Prices' (1982) 37 (2) Journal of Finance 275, 275.

${ }^{13}$ See further, Adolf Berle and Gardiner Means, The Modern Corporation and Private Property (Transaction Publishers, 1932).
} 
as measured by the stock price. It is understood that bank management are, by their nature, more risk averse. This is because a bank manager's human capital, reputational capital, private benefits of control, and financial capital are typically highly undiversified. As a result bank failure could impose significant costs on the bank's managers that would not be borne by its shareholders. ${ }^{14}$ The conventional account holds that it is desirable to induce managers, through incentives, to take risks, so that high venture projects with positive net present values are not rejected. This is premised on the belief that such risks are socially optimal. The critical issue then turns on just how much risk bank shareholders favour. This is where I depart from convention. As I will argue in Part C, bank shareholders prefer socially excessive risk-taking. By taking excessive risks, I refer to taking actions that may either increase or decrease the value of the bank's assets but whose expected effect on the bank's value is negative. $^{15}$

Recognising the weak link between non-equity compensation and managerial performance, shareholders encourage the use of equity-based compensation, typically in the form of stock options. The intuition here is that the stock price is an observable measure of performance and can therefore be used to indicate the effectiveness of managerial decisions, aligning the incentives of managers with shareholder interests. ${ }^{16}$ It follows that managers are induced to pursue shareholder maximisation because their compensation is made up of options, putting the manager in the shoes of the shareholder, which makes them focus on what the stock price is. The rationale for using equity-based compensation is widely supported. Nguyen and Nielsen suggest that an efficient managerial labour market should compensate executives according to their

\footnotetext{
${ }^{14}$ For example, an executive's professional standing would be adversely affected by a bank failure. Bebchuk and Jackson also recognise that in some circumstances, the bank may have deferred compensation programs and supplemental retirement account for their executives, and executives' rights under these programs might be adversely affected by such failure. See, Lucian Bebchuk and Robert Jackson, 'Executive Pensions' (2005) 30 Journal of Corporate Law 823. For further evidence on the use of such programs, see also, Rangarajan Sundaram and David Yermack, 'Pay Me Later: Inside Debt and its Role in Managerial Compensation' (2007) 62 Journal of Finance 1551.

${ }^{15}$ I adopt the same definition as used by Lucian Bebchuk and Holger Spamann. See, Lucian Bebchuk and Holger Spamann, 'Regulating Bankers' Pay' (2010) 98 Georgetown Law Journal 247.

${ }^{16}$ See, for example, Bengt Holmstrom and Jean Tirole, 'Market Liquidity and Performance Monitoring' (1993) 101(4) Journal of Political Economy 678. See also, ABI Guidelines on Executive Remuneration (December 2009).
} 
contribution to shareholder value. ${ }^{17}$ This is how equity-based compensation is supposed to work in practice: if executives make value enhancing decisions then this would increase firm value, as a result shareholder wealth increases, which, in turn, would reward executives. A study conduced by Hanlon, Rajgopal and Shelvin presents evidence that the granting of share option is linked to an increase in the future operating income of the firms investigated. ${ }^{18}$ This is not to say that the benefits are fully internalised to shareholder and managers. Indeed, in the case of banks, a more profitable bank has positive externalities to society. For example, it could help accelerate growth in the economy. Endorsing this shareholder-orientated model, Hansmann and Kraakman argue that social welfare is best served by encouraging corporate managers to pursue shareholder interests. ${ }^{19}$

\section{Excessive risk-taking and other problems}

Coming to the problem of excessive risk-taking. It has been widely recognised that managers had incentives to pursue excessive risk. I do not contend this. To guide us towards examining policies that can eliminate the incentives for excessive risk-taking, we must first attempt to identify the causation behind these incentives. In this regard, the conventional account, as advanced by Lucian Bebchuk and co-authors, suggests that inefficient, distorted and nontransparent structures of managerial incentives are a result of their power. ${ }^{20}$ They argue that directors have been influenced by management and this has enabled them to obtain 'rents'-benefits greater than those obtainable under true arm's-length contracting. ${ }^{21}$ There are a number of studies that appear to corroborate their

\footnotetext{
${ }^{17}$ Bang Dang Nguyen and Kasper Meisner Nielsen, 'What Death can Tell: Are Executives Paid for Their Contributions to Firm Value?' (March 2010) AFA 2011 Denver Meetings Paper.

${ }^{18}$ Michelle Hanlon, Shivaram Rajgopal and Terry Shelvin, 'Are Executive Stock Option Associated with Future Earnings' (2003) 36 Journal of Accounting and Economics 3.

${ }^{19}$ They argue that, "there is no longer any serious competitor to the view that corporate law should principally strive to increase long-term shareholder value". See, Henry Hansmann and Reinier Kraakman, 'The End of History for Corporate Law' (2001) 89 Georgetown Law Journal 439, 439.

${ }^{20}$ Lucian Bebchuk and Jesse Fried, Pay Without Performance: The Unfulfilled Promise of Executive Compensation, (Harvard University Press, 2004). See also, Lucian Bebchuk and Yaniv Grinstein, 'The Growth of Executive Pay' (2005) 21 Oxford Review of Economic Policy 282.

${ }^{21}$ ibid.
} 
claim that pay is higher, and less sensitive to performance, when executives have more power. ${ }^{22}$ According to this view, the design of managers' stock options has enabled managers to reap substantial rewards even when their own performance was merely passable or even poor. ${ }^{23}$ With options, it is alleged that executives have even more incentives for risk-taking than the common shareholders of bank holding companies.

As a result, managerial incentives are not aligned with the interests of shareholders. This is because the manager will fully capture stock price gains but will not fully bear stock price declines, as common shareholders would, ${ }^{24}$ especially if the shareholders are diversified and have holdings in 'real economy' companies. By having the freedom to exercise their options as soon as they vest and sell the underlying stock, managers were enabled to make considerable gains from temporary spikes in the company's stock price, even when long-term stock performance is poor. The insulation from shareholder losses meant that managers could focus exclusively on the upside and ignore the downside of any risk strategy. Managers could therefore be incentivised to make excessive risk decisions based on the opportunity to maximise their short-term personal wealth at the expense of long-term shareholder value. ${ }^{25}$ The burden of Bebchuk's argument is that, if the pay-offs from risk-taking are big enough, even undiversified managers will take big risks. In one study, Bebchuk et al, estimate that the top executive teams of Bear Stearns and Lehman Brothers derived cash flows of approximately $\$ 1.4$ billion and

\footnotetext{
${ }^{22}$ See, for example, John Core, Robert Holthausen, and David Larcker, 'Corporate Governance, Chief Executive Compensation, and Firm Performance' (1999) 51 Journal of Financial Economics 371 (finding outside directors who serve on three or more boards are more likely to be distracted.); Richard Cyert, Sok-Hyon Kang, and Praveen Kumar, 'Corporate Governance, Takeovers, and Top-Management Compensation: Theory and Evidence,' (2002) 48 Management Science 453 (showing CEO pay is $20 \%$ to $40 \%$ higher if the CEO is the chairman of the board, and it is negatively correlated with the stock ownership of compensation committee members.); Marianne Bertrand and Sendhil Mullainathan, 'Agents With and Without Principals' (2000) 90 American Economic Review 203 (finding in companies lacking large outside shareholders, boards make smaller reductions in cash compensation when they increase CEOs' option-based compensation.)

${ }^{23}$ Lucian Bebchuk and Jesse Fried, 'Pay Without Performance: Overview of the Issues' (2005) 17(4) Journal of Applied Corporate Finance 8, 18.

${ }^{24}$ Lucian Bebchuk and Holger Spamann, 'Regulating Bankers' Pay' (2010) 98 Georgetown Law Journal 247.

${ }^{25}$ See, for example, James March and Zor Shapira, 'Managerial Perspectives on Risk' (1987) 33(11) Management Science 1404.
} 
$\$ 1$ billion respectively from cash bonuses and equity sales during 2000$2008 .^{26}$ The implications of their analysis are that while shareholders lost the value of their shares, the bottom-line payoffs for managers were decidedly positive. Thus exemplifying a classic moral hazard problem. It is reiterated that according to the conventional account, the causation behind managerial risk-taking incentives is their power, showing that their incentives were not aligned with the interests of shareholders.

Managerial opportunism, ${ }^{27}$ whether in the form of expropriation of investors or of misallocation of company funds is said to reduce the amount of resources that investors are willing to put up ex ante to finance the firm. ${ }^{28}$ Furthermore, if financial arrangements do not enhance corporate governance then the mobilisation of savings from disparate agents and keep capital from flowing to profitable investment may be impeded. ${ }^{29}$ Another illustration of managerial power is that managers can expropriate shareholders by entrenching themselves and remain in their position even if they are no longer competent to run the firm. ${ }^{30}$ As argued by Jensen and Ruback, poor managers who resist being replaced might be the costliest manifestation of the "agency problem". ${ }^{31}$

\section{The conventional remedies}

The conventional account alleges that shareholders had inadequate rights so as to facilitate effective shareholder engagement. ${ }^{32}$ This view has driven

\footnotetext{
${ }^{26}$ Lucian Bebchuk, Alma Cohen and Holger Spamann, 'Wages of Failure: Executive Compensation at Bear Stearns and Lehman 2000-2008' (2010) 27 Yale Journal on Regulation 257.

27 See further, Andrei Shleifer and Robert Vishny, 'A Survey of Corporate Governance' (1997) 52(2) Journal of Finance 737.

${ }^{28}$ Sanford J Grossman and Oliver D Hart, 'The Costs and Benefits of Ownership: A Theory of Vertical and Lateral Integration' (1986) 94(4) Journal of Political Economy 691.

${ }^{29}$ Joseph Stiglitz and Andrew Weiss, 'Incentive Effects of Terminations:

Applications to the Credit and Labour Markets' (1983) 73(5) American Economic

Review 912.

${ }^{30}$ Andrei Shleifer and Robert Vishny, 'Management Entrenchment the Case of Management-Specific Investments' (1989) 25 Journal of Financial Economics 123.

${ }^{31}$ Michael Jensen and Richard Ruback, 'The Market for Corporate Control: The Scientific Evidence' (1983) 11 Journal of Financial Economics 5.

${ }^{32}$ See, for example, Lucian Bebchuk, 'The Case for Increasing Shareholder Power' (2005) 118(3) Harvard Law Review 833.
} 
shareholder-engagement high on the agenda in the U.S. and the U.K., ${ }^{33}$ which has led to a number of proposals aimed at limiting the deviations from shareholder interests. For example, Jensen and Murphy have recommended that, 'creating firm value' should not one of many objectives, but the firm's sole or governing objective. ${ }^{34}$ Lucian Bebchuk has made the case for reform that strengthens shareholder rights ${ }^{35}-\mathrm{a}$ proposition that has been supported by the Walker Review, which advocates greater integration of shareholders. ${ }^{36}$ This allows shareholders to better influence managerial behaviour. Among other things, this would allegedly discourage pay arrangements that reward executives for short-term gains and insulate them from losses to long-term shareholder value. To protect firm value, the shareholder-orientated model assigns shareholders a significant role in monitoring the riskiness of the activities executives are engaged with. A key result in the agency theory literature is that monitoring by a principal can allow improved contracts. ${ }^{37}$ This development is said to help eliminate risk-taking incentives that are excessive from the shareholders' perspective. ${ }^{38}$ According to this view, increasing bank shareholder engagement would provide superior risk management, reducing excessive risk-taking.

However, in section C:7, such proposals will be shown to be highly controversial. It will be argued that at present, greater accountability by bank boards to shareholders is incapable of reducing excessive risk-taking, and may instead, exacerbate the problem. The case for the conventional account rests on the assumption that excessive risk-taking is not shareholder driven. Opposite to this, in Part C, I will show that the more convincing argument is that exposure to shareholder pressure lead management to accept greater risk.

\footnotetext{
${ }^{33}$ For example, The Dodd-Frank Wall Street Reform and Consumer Protection Act, H.R. 4173, 111th Cong., from 951-956. See also, The U.K. Stewardship Code (2010).

${ }^{34}$ Michael Jensen and Kevin Murphy, 'Remuneration: Where we've been, how we got here, what are the problems and how to fix them' (2004) ECGI Finance Working Paper No. 44/2004.

${ }^{35}$ See, Lucian Bebchuk, 'Letting Shareholder Set the Rules' (2006) 119 Harvard Law Review 1784.

${ }^{36}$ The Walker Review: 'A Review of Corporate Governance in UK Banks and Other Financial Industry Entities' Final Recommendations (November 2009) at Ch.5.

${ }^{37}$ Douglas Diamond, 'Financial Intermediation as Delegated Monitoring: A Simplistic Example' (1996) 82(3) Federal Reserve Bank of Richmond Economic Quarterly 51, 53.

${ }^{38}$ Lucian Bebchuk, 'How To Fix Bankers' Pay’ (2010) 139(4) Daedalus.
} 


\section{The Limitations of the Current Shareholder-Orientated MODEl IN A BANK SETTING}

Here, I argue that excessive risk-taking is also partly a product of the conventional model. There are two steps in this account. The first is an articulation of key factors that incentivise bank shareholders to prefer excessive risk-taking. Before proceeding, I recognise that many of these factors identified are also the same for managers. They have, however, received comparatively little attention in relation to shareholders. The second step is that bank shareholders play a key role in shaping the investment policy of the bank-by pressuring their management to accept greater risk. It is this step which drives the argument towards excessive risk-taking being shareholder push rather than managerial pull. Brining out the causal links guides the discussion towards considering what avenues of policy are promising to develop to mitigate excessive risktaking.

\section{Limited liability and internalisation of costs}

The intuition behind the assumption that shareholders are averse excessive risk is as follows. Shareholders stand to lose their investment in the event of failure. The risk of this loss, the conventional narrative suggests, acts as a sufficient incentive for shareholders to control risk. However, the alternative narrative developed here casts considerable doubt on this assumption. A first step to understanding why shareholders would be in favour of excessive risk is that they benefit from limited liability. This means that the holders of the equity stand to benefit from the upside of the risky project, for example through an increase in dividends during good times. However, their downside loss is capped to the equity they have at the time the project is undertaken. The gains made on the upside of excessive risk taking are not repayable on failure, assuming the shareholders have taken the gains out of the bank, either through distributions or share sales. Concededly, this may be truer of managers, before the recent reforms to remuneration schemes. Shareholders would certainly suffer some loss if the project is a disaster and the bank fails, however, they do not to internalise the costs of systemic risk associated with bank failure, ${ }^{39}$ such costs are borne, at least

\footnotetext{
${ }^{39}$ See, Jeffrey Gordon, 'Say on Pay: Cautionary Notes' (2009) 46 Harvard Law School Journal on Legislation 323, 365.
} 
in part, by taxpayers. As a characteristic example, after suffering a collapse in the financial sector, Ireland have been reliant on an external assistance package worth $€ 67.5 \mathrm{bn} .{ }^{40}$ These costs far outstrip a bank's internal and direct losses. Moreover, in the U.S., Federal programs made up of lending and guarantee commitments to various credit market participants was up to $\$ 7.7$ trillion. $^{41}$ The insulation from the taxpayer costs associated with failure produces two pronounced problems. First, it encourages over-investment in risky projects. This holds that shareholders induce bank management to take excessive risks, which result in a negative value for taxpayers, but due to the insulation from downside risks, could carry a positive expected value for bank shareholders. What this shows is the divergence between what is privately optimal risk-taking and what is socially optimal. Second, inefficiency is created: inadequate levels of care and under-investment in precautions, such as monitoring, against excessive risk.

Convention might suggest that other mechanisms operate to internalise the costs of risk. However, as Armour and Gordon, who make the case for additional liability on bank directors, explain, regulatory controls are actively undermined by the conventional model and none of the ordinary internalisation mechanisms can be relied upon to protect society. ${ }^{42}$ This exposes a critical issue with the conventional model when applied to banks. It assumes that the costs of failure are largely internalised by the firm and so are taken into account when shareholders determine their risk appetite. If this is not the case, as has been shown with banks, then the shareholders' risk appetite may be socially excessive. The analysis points towards an incentive incompatibility. It follows from the foregoing that shareholders have incentives to pressure the firm to take on more risk than is desirable, for example, the debt holders of the bank. ${ }^{43}$ This is because the debt holders do not stand to benefit from the

\footnotetext{
${ }^{40}$ The assistance package was funded by the European Financial Stability Mechanism, the IMF, the European Stability Facility and bilateral loans. - Independent Commission on Banking, Interim Report: Consultation on Reform Options, (April 2011), 22, [2.24].

${ }^{41}$ Phil Kuntz and Bob Ivry, Fed Once Secret Price Data Compiled by Bloomberg Released to Public, Bloomberg, 23 December, 2011.

42 John Armour and Jeffrey Gordon, 'Systemic Harms and the Limits of Shareholder Value' (2013) ALEA.

${ }^{43}$ This is consistent with findings from: Dan Galai and Ronald Masulis, 'The Option Pricing Model and the Risk Factor of Stock' (1976) 3 Journal of Financial Economics 53. See also, Harold Demsetz and Kenneth Lehn, 'The Structure of Corporate Ownership: Causes and Consequences' (1985) 93(6) Journal of Political Economy 1155.
} 
upside from the risky projects. As a result, a conflict exists between shareholder wealth maximisation and financial stability.

\section{Distinguishing shareholders}

At this point, it is helpful to disaggregate shareholders. This paper relates the distinction on the types of bank shareholders to one piece of literature. Jeffrey Gordon identifies a key divide in bank shareholders between the blockholders and diversified shareholders. ${ }^{44}$

\section{(a) Blockholders and risk}

Pursuant to the alternative narrative, Gordon claims that the blockholder may be willing to take excessive risk because it internalises the upside but not much of the systemic downside. ${ }^{45}$ In support of this view, Laeven and Levine show in an empirical assessment that banks with higher controlling shareholder ownership tend to be riskier. ${ }^{46}$ This can be explained through the greater incentives large shareholders have to invest resources in governance activism that can influence managerial behaviour. This is because they would stand to capture more of the gains from the excessive risks. Moreover, the blockholder will typically have larger voting and cashflow rights, conferring greater power to shape corporate behavior than smaller owners. ${ }^{47}$ Erkens, Hung, and Matos, using a sample of 296 firms from thirty countries, find that firms with more independent boards and higher institutional ownership experienced worse stock returns during the GFC. ${ }^{48}$ They conclude that firms with higher institutional ownership took "...greater risk in their investment policies before the onset of the crisis." 49 This conclusion is, at least, consistent with the view that blockholders pressured management to take on greater risk - which was to

\footnotetext{
${ }^{44}$ Jeffrey Gordon, 'Executive Compensation and Corporate Governance in Financial Firms: The Case for Convertible Equity-Based Pay' Columbia Law School and European Corporate Governance Institute Working Paper No.373 (2010).

${ }^{45}$ ibid, 6.

${ }^{46}$ Luc Laeven and Ross Levine, 'Bank Governance, Regulation and Risk Taking' (2009) 93(2) Journal of Financial Economics 259.

${ }^{47}$ See, Andrei Shleifer and Robert Vishny, 'Large Shareholders and Corporate Control' (1986) 94(3) Journal of Political Economy 461.

${ }^{48}$ David Erkens, Mingyi Hung and Pedro Matos, 'Corporate Governance in the 20072008 Financial Crisis: Evidence from Financial Institutions Worldwide' (2012) 18(2) Journal of Corporate Finance 389.

${ }^{49}$ ibid, 390.
} 
be to the detriment of bank stability. I now turn to contrast the risk appetite of blockholders with that of diversified shareholders.

\section{(b) Diversified shareholders and risk}

Limited liability allows more efficient diversification - a point emphasised by Henry Manne. ${ }^{50}$ Ordinarily investors can minimise risk by owning a diversified portfolio of assets. The intuition here is that in the event that one of the companies in their portfolio fails, their loss would be minimised to one small part of the portfolio. The narrative for banks, however, plausibly changes. It is at this point that Gordon's concerns come to the fore. This brings us to a difference of opinion between Gordon and me on the risk appetite of diversified bank shareholders. His claim is that if the risk within the bank materialises and the bank fails, the diversified shareholder would suffer losses beyond their holding of equity in the bank, namely through their holding of equity in all of the other companies in their portfolio. This is because the expected profitability of many non-financial firms will be lowered via knock-on effects from contraction in the financial sector. For a bank shareholder, the systemic risk damages are therefore amplified through diversification. The benefits from an increase in the value of the shareholder's holdings of equity are likely to be outweighed by the reduction in value of the portfolio as a whole. Gordon concludes that this effect means that diversified bank shareholders do not have incentives to encourage managers to take excessive risks. ${ }^{51}$

\section{An expectation of bailout}

Although Gordon provides illuminating analysis on the position of diversified bank shareholders, I cast a somewhat skeptical look at his claims. The reason for this skepticism is that his explanation only works when shorn of the expectation of bank bailouts. In essence, it is assumed that the bank will be allowed to fail. However, this brings back into focus one of the central themes of this paper- that is, banks are different. To

\footnotetext{
${ }^{50}$ Henry Manne, 'Our Two Corporation Systems: Law and Economics' (1967) 53(2) Virginia Law Review 259.

${ }^{51}$ Jeffrey Gordon, 'Executive Compensation and Corporate Governance in Financial Firms: The Case for Convertible Equity-Based Pay' Columbia Law School and European Corporate Governance Institute Working Paper No.373 (2010), 3.
} 
avoid the costs associated with bank failure, governments across the U.S. and Europe have provided financial assistance to systemically important financial institutions close to insolvency. ${ }^{52}$ This created an expectation that other systemically important financial institutions approaching the brink of insolvency could rely on the likelihood of financial assistance from the government. The expectation of bank bailout alters the comparatively lower risk appetite of diversified shareholders' suggested by Gordon. Suppose a bank approaching insolvency receives a bail out and consequently does not fail, any implications from systemic risk for the bank taking excessive risk would be minimised. When the bank engages in risk-taking activities it earns a risk premium for the risk it takes on, this translates into dividends for the shareholders. Diversified shareholders therefore stand to benefit from the upside of the risk-taking but would suffer little downside consequence to their market portfolio because the government intervenes to bail the bank out. Based on this expectation, the risk appetite of bank shareholders, on both sides of the divide, may be socially excessive.

\section{Deposit insurance}

The anticipation of bank bailout is one example of a more general problem that is most clearly exemplified by the too-big-to-fail (TBTF) status of many financial institutions. ${ }^{53}$ As a consequence to this status, many countries operate a system of state-backed deposit-guarantee schemes (DGS). Deposit insurance "...has succeeded in achieving what had been a major objective of banking reform for at least a century, namely the prevention of banking panics." ${ }^{, 54}$ Despite the positive effects of DGS on preventing bank runs it also has negative side effects by incentivising bank shareholders to engage in excessive risk-taking, displaying a clear example of moral hazard. This is because bank shareholders stand to capture the full upside of the risk, while some of the

\footnotetext{
${ }^{52}$ Commitments to support the financial sector in the recent financial crisis peaked at 50 per cent of GDP in the U.S. and 70 per cent in the U.K. See, Bank of England, 26 Financial Stability Report, 6 (2009).

${ }^{53}$ See for example, Nassim Taleb and Charles Tapiero, 'Too Big to Fail, Too Big to Bear, and Risk Externalities' (2009) New York University Polytechnic Institute Research Paper.

${ }^{54}$ Milton Friedman and Anna Schwartz, A Monetary History of the United States (Princeton University Press, 1963) p. 440.
} 
downside will be borne by government, as insurer of deposits should the bank become insolvent. Hence, the government insurer charges riskrelated deposit insurance premiums. Unfortunately, “...deposit insurance premiums have been unrelated to, or have not fully compensated...for increased risk posed by a particular bank." ${ }^{, 55}$ One reason for this is that government, in part, due to political concerns, has constraints that limit their ability to discriminate between banks having different risks of failure. "Ac "Accordingly, banks are able to finance various projects at interest costs that are not commensurate with the risk of the projects..." ${ }^{57}$ Risk-insensitive deposit insurance means that the risk is shifted on to the deposit insurer. Moreover, shareholders can use their control position to cause banks to engage in increasingly risky activities in order to transfer wealth from creditors, depositors, and ultimately the deposit insurance fund itself, to the shareholders of DGS banks. ${ }^{58}$ The difference between between non-financial firms and banks is that banks can raise deposits more cheaply even if they are engaging in risky behaviour. While risktaking by non-financial institutions close to insolvency is constrained by market forces and contractual undertakings, which their shareholders will take into account, banks in a similar condition can continue to attract liquidity, due to deposit insurance. ${ }^{59}$ This substantiates the point made above, that bank shareholders will not take into account, when determining their risk appetite, the costs of failure, hence their risk appetite may be socially excessive.

\section{High levels of leverage}

Financial institutions can quickly increase its profitability by increasing its leverage. Financial leverage is desirable to shareholders as it can be used to increase the value of their equity call options. ${ }^{60}$ For any given

\footnotetext{
${ }^{55}$ George Hanc, 'Deposit Insurance Reform: State of the Debate' (1999) 12(3) Federal Deposit Insurance Corporation Banking Review 1, 3.

${ }^{56}$ George Pennacchi, 'Deposit Insurance' (2009) AEI Conference on Private Markets and Public Insurance Programs, August 2009.

${ }^{57}$ George Hanc, 'Deposit Insurance Reform: State of the Debate' (1999) 12(3) Federal Deposit Insurance Corporation Banking Review 1, 3.

${ }^{58}$ Jonathan Macey and Geoffrey Miller, 'Bank Failures, Risk Monitoring and the Market for Bank Control' (1988) 88 Columbia Law Review 1153, 1165.

59 Jonathan Macey and Maureen O'Hara, 'Corporate Governance of Banks' (2003) Apr. Economic Policy Review 91, 98.

${ }^{60}$ Anthony Saunders, Elizabeth Strock and Nickolaos Travlos, 'Ownership Structure, Deregulation, and Bank Risk Taking' (1990) 45(2) Journal of Finance 643, 644.
} 
overall level of capital invested in the firm, a higher ratio of debt to equity limits the firm's potential liability even further. This means that debt financing accentuates the disincentive to invest in safety and the incentive to over-invest in hazardous industries. ${ }^{61}$

As previously discussed DGS renders debt a cheap source of funds and therefore biases banks toward it. ${ }^{62}$ Debt and equity would be equally expensive under the Modigliani-Miller theorem, ${ }^{63}$ however, in banks this is not necessarily the case. The implicit reduction in interest expense charged to TBTF banks creates an opportunity for cheap capital that cannot be spurned. ${ }^{64}$ This induces bank shareholders to pressure management to take full advantage of this cheap capital, increasing capital- to-asset ratios in the process. A clear example of this is in the U.K., where the ratio of debt to shareholders' capital in banks can be seen to be much higher than non-financial firms. ${ }^{65}$ One significant implication of this is that banks have a thin layer of absorbable equity, which heightens the risk of failure. Shareholders' preference for leverage is complemented by the creditors' continuing expectation, as outlined above, that they will be protected in a federally-assisted rescue of a failing financial institution. ${ }^{66}$ In effect, shareholders are afforded a level of protection, not only from the externalities associated with failure, but from the bank being allowed to fail in the first place, giving shareholders the motivation to seek to maximise the opportunity of cheap capital.

\section{Shareholder Pressure}

In the preceding sections, I have explained how excessive risk-taking is in the rational self-interest of bank shareholders given the key risk-inducing

\footnotetext{
${ }^{61}$ Henry Hansmann and Reinier Kraakman, 'Toward Unlimited Shareholder Liability for Corporate Torts' (1991) 100 (7) Yale Law Journal 1879, 1884.

${ }^{62}$ See further, Hamid Mehran, Alan Morrison and Joel Shapiro, 'Corporate Governance and Banks: What Have We Learned from the Financial Crisis?' Federal Reserve Bank of New York (2011) Staff Report no.502, 4.

${ }^{63}$ Franco Modigliani and Merton Miller, 'The Cost of Capital, Corporation Finance and the Theory of Investment' (1958) 48(3) American Economic Review 261.

${ }^{64}$ John Coffee, 'The Political Economy of Dodd-Frank: Why Financial Reform Tends to be Frustrated and Systemic Risk Perpetuated' (2012) 97 Cornell Law Review 1019, 1053.

${ }^{65}$ See, Independent Commission on Banking, Interim Report: Consultation on Reform Options, (April 2011).

${ }^{66}$ John Coffee, 'The Political Economy of Dodd-Frank: Why Financial Reform Tends to be Frustrated and Systemic Risk Perpetuated' (2012) 97 Cornell Law Review 1019, 1054.
} 
factors that have been discussed. However, the limitations of the first step should be noted. Causation has not yet been identified. The point at present is that bank shareholders' risk appetite is socially excessive. For the explanation offered in this paper to work, the bank's investment policy would have to reflect this preference by shareholders pressuring their management to accept higher risk. The second step in this account brings the discussion to consider two mechanisms through which exposure to shareholders leads managers to take more risk. The first mechanism used to advance shareholder interests is through the design of pay-by increasing managerial pay contingent on the performance of firm value, typically in the form of stock options. As outlined in section I.C, such was the design of incentives, managers were induced to focus on increasing the short-term stock price, to the detriment of long- term firm value. Elijah Brewer III et al find evidence of a positive correlation between the increase of equity-based compensation in the U.S. banking sector in the 1990s and an increase in risk- taking. ${ }^{67}$ Allied with this, a study by Cheng et al, finds the level of residual pay is especially correlated with the firm's beta and other measures of risk. This is consistent with the argument that executives were rewarded or encouraged to take excessive risks. The authors also find evidence that executives, who received the highest remuneration in the years leading up to the financial crisis of 2008-2009, were those in firms that performed the worst during the crisis. ${ }^{68}$ The critical point here is that these high-powered incentives could be what the shareholders of the bank wanted. Bank shareholders have been argued to be a force for greater risk-taking, therefore the more you align managerial incentives with shareholders the more there is a shift towards a higher acceptance of risk. This suggests that high-powered incentives are simply the carrot needed to get the bank to take risks desired by its shareholders. ${ }^{69}$ Indeed as John Coffee explains, "to 'correct' the managerial tendency toward risk aversion, shareholders might have been

\footnotetext{
${ }^{67}$ Elijah Brewer III, William Hunter and William Jackson III, 'Deregulation and the Relationship Between Bank CEO Compensation and Risk-Taking' (2003) Federal Reserve Bank of Chicago Working Paper No. 2003-32. Bengt Holmstrom and Steven Kaplan suggest that the dramatic rise in shareholder influence that began in the 1980s explains the aggressive use of stock options. See, Bengt Holmstrom and Steven Kaplan, Corporate Governance and Merger Activity in the United States: Making Sense of the 1980s and 1990s' (2001) 15 Journal of Economic Perspectives 121. ${ }^{68}$ Ing-Haw Cheng, Harrison Hong and Jose Scheinkman, 'Yesterday's Heroes: Compensation and Creative Risk- Taking' (2010) NBER Working Paper No.16176. ${ }^{69}$ ibid, 5.
} 
willing to accept even imperfect compensation formulas to seduce managers into accepting increased risk." ${ }^{, 70}$

A manager's survival in office relies on the maximisation of shareholder value. Shareholders may threaten managers with removal or loss of control if they reject risky projects that would increase the share price. One measure that could be helpful in determining the effectiveness of this mechanism is to examine managerial turnover rates. Kaplan and Minton observe that since 1998 managerial turnover in the U.S. increased meaningfully. Not counting takeovers, $12.4 \%$ of CEOs turned over each year, on average, from 1998 to 2003 and $12.2 \%$ of CEOs turned over each year, on average, from 2004 to 2010. They find a significant positive relationship relative to the turnover- performance sensitivity between performance and block shareholder ownership. ${ }^{71}$ Although the sample used in the study is taken from a cross-industry selection of large companies, the point to be made is that the threat of removal is an effective mechanism that allows bank shareholders to pressure their management to accept greater risk. It becomes realistic to suggest that managers not accepting of the levels of risk preferred by shareholders would be removed from office. Certainly, the blockholder would be in a position to exercise control and remove management. As a result, undiversified managers with greater exposure to removal by shareholders would be highly incentivised to accept greater risk. The analysis above indicates that these two mechanisms can help explain the excessive risktaking of banks.

Suppose we were to accept the conventional account, we would expect banks with shareholder-friendly boards, which is taken to mean boards with a strong alignment with shareholder interests, to fare better. There is compelling evidence to the contrary. Fahlenbrach and Stulz find evidence that those banks with CEOs whose incentives were better aligned with their shareholders performed worse during the crisis. They conclude that, "CEOs with better incentives to maximise shareholder wealth took risks that other CEOs did not." ${ }^{, 72}$ In another study, Beltratti

\footnotetext{
${ }^{70}$ John Coffee, 'The Political Economy of Dodd-Frank: Why Financial Reform Tends to be Frustrated and Systemic Risk Perpetuated' (2012) 97 Cornell Law Review 1019, 1053.

${ }^{71}$ Steven Kaplan and Bernadette Minton, 'How Has CEO Turnover Changed?' (2012) 12(1) International Review of Finance 57.

${ }^{72}$ Rudiger Fahlenbrach and Rene Stulz, 'Bank CEO Incentives and the Credit Crisis' (2011) 99 Journal of Financial Economics 11, 25.
} 
and Stulz analyse the significant variation in the cross-section of stock returns of large banks across the world during July 2007 to December 2008. They find in correlation that banks with a shareholder-friendly board performed worse during the crisis. ${ }^{73}$ While these findings can be interpreted as being consistent with the view that shareholder pressure led managers to accept greater risk, these studies find correlation, not causation. Moreover, it might be suggested these findings may also be consistent with the conventional account. As my analysis of the conventional account suggests, undiversified managers are risk averse, as a result, shareholders would want managers to take more risks. In the case of an unexpected shock to the system, those risks would lead to less good performance. It is still ambiguous whether excessive risk-taking is shareholder push or managerial pull.

A study by Ferreira et al shows that management insulation can be used as a predictor of bank bailouts. They find that banks in which managers are fully insulated from shareholders are roughly 19 to 26 percentage points less likely to be bailed out. ${ }^{74}$ The bailout being a measure of failure ex post. The authors interpret this as meaning that banks with managers less insulted, took on more risk and were therefore more likely to fail. Chen reaches similar results, finding that CEOs who are insulated from shareholder pressure and do not receive high-powered pay are less prone to engage in risk-taking. ${ }^{75}$ The results do not give much comfort to the believer in the conventional model. These are important studies for the alternative account as they provide, in correlation, evidence that shareholder push rather than managerial pull was behind bank risk-taking. This previously missing evidence suggests that the thesis presented holds validity.

The foregoing analysis reveals that two problems exist. The first, put forward by the conventional account is that compensation arrangements created excessive incentives for bank managers to engage in risky activities. The second problem identified in this paper, made up of two

\footnotetext{
${ }^{73}$ Andrea Beltratti and Rene Stulz, 'The Credit Crisis Around the Globe: Why Did Some Banks Perform Better?' (2011) Fisher College of Business Working Paper Series.

74 Daniel Ferreira, David Kershaw, Tom Kirchmaier and Edmund Schuster 'Shareholder Empowerment and Bank Bailouts' (2013) European Corporate Governance Institute Finance Working Paper No.345.

${ }^{75}$ Carl R. Chen, 'Does Stock Option-Based Compensation Induce Risk-Taking? An Analysis of the Banking Industry' (2006) 30 Journal of Banking and Finance 915.
} 
parts, is that (1) bank shareholders' risk appetite is socially excessive and (2) exposure to shareholder pressure leads managers to take more risk. We should not choose between these problems-both need to be adequately addressed. This paper will now consider the extent to which current corporate governance reforms addresses these problems.

\section{Why managerial incentives reforms are not enough?}

Given the nature of the problem of incentives it is common to look to corporate governance reforms as the solution. The flaws in managerial compensation arrangements have prompted a plethora of policies aimed at making manager's earnings sensitive to the risks run to acquire the earnings. ${ }^{76}$ This is a step in the right direction and such measures can discourage some risk-taking. However, they do little to mitigate the bank shareholder problem identified. No matter how risk sensitive the performance related pay of managers is made, bank shareholders have other means by which to pressure and incentivise their management to accept greater risk. An example already given is the threat of removal, which the analysis in this paper has shown can also highly incentivise managers to take risks.

What is worse, another common response has been for legislators and regulators to adopt measures aimed at empowering shareholders to prevent deviation from shareholder interests, which may instead exacerbate the problem. For instance, in the U.S., the ability of bank shareholders to pressure their management to accept greater risk has been significantly enhanced. By giving shareholders access to the proxy statement, the SEC Rule 14a-11 intends to facilitate the ability of dissident shareholders to place their nominees on the corporate board at low cost, giving shareholders a stronger voice on the board. ${ }^{77}$ Similarly, in the U.K.,

\footnotetext{
${ }^{76}$ See, Financial Stability Board, Financial Stability Forum Principles for Sound Compensation Practices, April 2, 2009; 12 U.S.C. $\S$ 5221(b)(3)(D)(i) (2009) (codifying the EESA and incorporating amendments pursuant to the American Recovery and Reinvestment Act of 2009). The stimulus bill requires that incentive compensation for top officers and employees of TARP recipients be exclusively in long-term restricted common stock. See also, The Committee of European Banking Supervisors, Guidelines on Remuneration Policies and Practices, December 10, 2010;

${ }^{77}$ The Securities Act Release No. 33-9136 ("Facilitating Shareholder Communication") (August 25, 2010). For further analysis of the rule in relation to such arguments see, John Coffee, 'Systemic Risk After Dodd-Frank: Contingent Capital and the Need for Regulatory Strategies Beyond Oversight' (2011) 111 Columbia Law Review 795, 814.
} 
changes to the U.K. Corporate Governance Code aims to increase the accountability to shareholders. ${ }^{78}$ It should be noted that this is a general corporate reform, not a bank specific one. For the reasons above, excessive risks from a social perspective are not necessarily excessive from bank shareholders' perspective. Therefore, from a systemic risk perspective, it cannot be assumed that bank shareholders are the champion of moderation. These measures do nothing to limit the risk appetite of bank shareholders and, as a result, cannot be expected to eliminate incentives to take socially excessive risks. Instead, by increasing shareholder engagement, this would plausibly lead to more of the same excessive risktaking, policy makers are aiming to mitigate. The bottom line is then, in the absence of reducing bank shareholders' appetite for risk, empowering shareholders may not only not be the answer, it may compound the problem. Viewed in this light, it seems one promising avenue would be to modify the conventional model so as to refashion the incentives of bank shareholders.

\section{INTRODUCING THE BANK SHAREHOLDER-ORIENTATED MOdEL}

The bank shareholder risk diagnosis offered opens space for policy instruments, which reduce the risk appetite of bank shareholders. In this section, double bank shareholder liability is presented as a modification to the conventional model to achieve this. From the outset, it is acknowledged that a regime of double liability would impose numerous costs, for example, the indirect social costs of efforts to evade liability, and is therefore not a policy without its flaws. However, it is argued that such a regime has substantial merits in both its deterrent effect against excessive risk-taking and its incentive effect to induce bank shareholders to more effectively monitor, investigate and control risk - an important activity goal. To both illustrate and test this proposition, the functioning of double liability is analysed in one historical epoch: the United States from 1863 to 1933. Throughout, this section, I acknowledge and respond to likely objections to double liability.

\section{A double liability standard}

${ }^{78}$ Financial Reporting Council, The U.K. Corporate Governance Code, 2010, 1-5. 
As I have repeatedly emphasised, the problem with the conventional model when applied to banks is that it assumes that the costs of failure are largely internalised by the firm and so are taken into account when shareholders determine their risk appetite. Analysis has shown that this is not the case with banks, hence bank shareholders' risk appetite is socially excessive. As a result, the conventional model does not work to the benefit of social welfare because of the externalities attached to bank failure. There is another technique that could be used in governance, which is to cause shareholders to suffer additional liability in the event of failure. This signals a departure from a central characteristic of modern corporate law-the current limited liability rule. One way this can be done is to impose a regime of double liability. Under double liability, shareholders of failing banks stand to lose, first, the initial cost of their shares in the bank. Then, if the bank's assets are insufficient to pay off its depositors and other creditors, shareholders are exposed to an additional amount up to, but not exceeding, the par value of their stock in the bank. This is counted as their contribution toward making up the difference between the bank's assets and liabilities. Whereas previous literature and justification for double liability has revolved around protecting bank creditors, my work differs in a relatively novel way. The main focus of the regime in this paper is the extent to which it can reduce bank shareholders' risk appetite. It is to this aspect of the regime I turn to next.

\section{Risk-taking and risk management}

Macey and Miller argue that double liability transforms shareholders from investors seeking to advantage themselves at the expense of other investors by increasing the riskiness of the banks in which they have invested, into investors who benefit themselves by decreasing the riskiness of these firms. ${ }^{79}$ Bank shareholders exposed to double liability may legitimately be more conservative in evaluating an investment that brings socially excessive risk because bank failure would impose a higher cost on them than under the current regime. Under the existing model, bank shareholders are induced to displace as much cost of the bank's risky activities to taxpayers as possible. Concededly, double liability would not

\footnotetext{
${ }^{79}$ Jonathan Macey and Geoffrey Miller, 'Double Liability of Bank Shareholders: History and Implications' (1992) 27 Wake Forest Law Review 31, 33.
} 
be linked to the size of the failure externalities. However, the regime provides an improved level of cost internalisation. Moreover, the contingent additional loss shareholders face if the bank fails would reduce the risk appetite of bank shareholders, making them more risk averse. This may deter shareholders from pressuring their management to accept socially excessive risk. In this situation, the improved level of cost internalisation means that bank shareholders would be more likely to take into account the costs of their investment projects. It follows that this could be reflected in the bank's investment policy, reducing its riskiness. To illustrate this incentive effect in practice, two examples are given. In an important study, using data from 1900 to 1915, focusing on solvent banks, Benjamin Etsy analyses whether the regime of double liability had any effect on their risk-taking behaviour. The study finds in correlation, that banks subject to double liability held a lower proportion of risky assets, especially at low levels of net worth. More importantly, double liability appeared to discourage banks from investing in risky assets as their net worth declines. In a separate but corroborating analysis on California banks, Etsy observes that in conversion from state to national charter, which corresponds to a decrease in shareholder liability, there was an in increase in risk-taking. ${ }^{80}$ In another study, Richard Grossman examines the relationship between double liability and bank risk-taking during 1892 to 1930, using balance sheet and failure data to proxy for risk-taking, controlling for macroeconomic and regulatory conditions, as they may affect the various measure for risk-taking. The study finds evidence that suggests double liability did reduce risk-taking among banks in the late nineteenth and early twentieth centuries. The effects of double liability in the study can be seen through a correlation between lower failure rates, higher capital ratios, and higher liquidity ratios with state banks in multiple-liability states. ${ }^{81}$ Put together, these correlations can, at least, be viewed as consistent with the argument that double liability deters excessive bank risk-taking by reducing bank shareholders' risk appetite.

\footnotetext{
${ }^{80}$ Benjamin Esty, 'The Impact of Contingent Liability on Commercial Bank Risk Taking' (1998) 47 Journal of Financial Economics 189.

${ }^{81}$ Richard Grossman, 'Double Liability and Bank Risk Taking' (2001) 33(2) (1) Journal of Money, Credit and Banking 143.
} 


\section{RECOVERY}

So far, in Part C, this paper has analysed the incentive effects of double liability in discouraging excessive risk-taking. Here, I consider data on the recovery from shareholders-an important aspect of the regime-to determine its effectiveness. When Congress passed the 1863 Act, it largely ignored enforcement details. Instead, a combination of legislative action and judicial decisions ultimately established the enforcement mechanisms. A similar approach could be taken. According to Macey and Miller the Comptroller of the Currency collected $51 \%$ of assessments made between 1865 and 1934, an amount equal to $28 \%$ of creditor losses in national banks. ${ }^{82}$ Upham and Lamke report that state regulators collected $43.8 \%$ of assessments made between 1921 and $1930 .{ }^{83}$ While recovery rates under this regime are far from perfect, it should be noted that bank managers and directors were often large shareholders. When a bank failed, they lost both their human and financial capital, yet were still able to pay a large fraction of the assessments. ${ }^{84}$

A second piece of evidence on the credibility and effectiveness of double liability cited by Etsy is the number of voluntary bank closures. Etsy argues that since 1933, under limited liability, bank shareholders have had no incentive to close voluntarily because that would extinguish their call option on the bank's assets. ${ }^{85}$ In contrast, under double liability, from 1865 to 1933 , voluntary liquidations accounted for $70 \%$ of the 8302 national-bank liquidations, and over $80 \%$ of the liquidations from 1865 to $1912 .{ }^{86}$

This data shows that under the previous double liability regime, Federal regulators had the legal precedence and enforcement mechanisms to collect meaningfully from shareholders. As Macey and Miller conclude "that it was not perfect is no objection to its efficacy; no

\footnotetext{
82 Jonathan Macey and Geoffrey Miller, 'Double Liability of Bank Shareholders: History and Implications' (1992) 27

Wake Forest Law Review 31.

${ }^{83}$ Cyril Bryce Upham and Edwin Lamke, Closed and Distressed Banks: A Study in Public Administration, (Brookings Institution, 1934).

${ }^{84}$ Benjamin Esty, 'The Impact of Contingent Liability on Commercial Bank Risk Taking' (1998) 47 Journal of Financial Economics 189, 192.

${ }^{85}$ ibid, 193.

${ }^{86}$ ibid.
} 
regulatory program is perfect, and the one that supplanted double liabilitydeposit insurance-certainly is not". ${ }^{87}$

\section{Shareholder engagement}

If we take the conclusion that double liability does reduce bank shareholders' risk appetite, at this point, shareholders on both sides of the divide articulated earlier, should be a good proxy for society. Double liability then, would induce bank shareholders to undertake more monitoring and investigating to control risk. This is where I become supportive to measures aimed at increasing shareholder powers and engagement. Relying on shareholder activism is more desirable than government intervention. This is because firms will often have more information and potentially better expertise than government officials at monitoring or investigating managers. However, after assigning shareholders a greater role in the monitoring and policing of managerial risk-taking decisions, there may arise a concern about an increase in cost barriers. There are two points to be made here. The first is that the costs of activism could be reduced since double liability, by imposing contingent additional costs, motivates both the blockholder and the diversified shareholder to engage in activism to control risk. Collective activism would reduce the costs associated with further shareholder engagement. The second point, to partly address the free-rider problem and further reduce cost barriers, is to introduce a reimbursement rule. Lucian Bebchuk makes a proposal of this character, whereby, shareholders who initiate proposals that gain a substantial number of votes would be reimbursed by the company. ${ }^{88}$ These elements are an effort to give shareholders the power to monitor, investigate and control risk optimally, with as little cost barriers as possible.

One response to my support of proposals to increase shareholder engagement might be that, as agency theory recognises, we do not have to rely exclusively on shareholders to monitor and control risk. In line with this view, legislators and regulators have put forward measures

\footnotetext{
${ }^{87}$ Jonathan Macey and Geoffrey Miller, 'Double Liability of Bank Shareholders: History and Implications' (1992) 27 Wake Forest Law Review 31, 35.

${ }^{88}$ Lucian Bebchuk, 'Letting Shareholder Set the Rules' (2006) 119 Harvard Law Review 1784, 1799.
} 
for bolstering the role of independent directors. ${ }^{89}$ Effective, independent directors who inject the interests of taxpayers into the risk management of the bank, may at once, weaken the case for the need to reduce the risk appetite of bank shareholders and make redundant the proposal of double liability. However, it is not immediately clear that independent directors are aligned with taxpayers' interests. As Bebchuk and Spamann acknowledge, "even in the ideal model, independent directors are elected by and represent shareholders who [...] have incentives to take higher risks than would be socially optimal." ${ }^{90}$ Significantly, in this case, independent directors represent an additional resource for shareholders that can pressure management to accept greater risk. Consequently, independent directors cannot be expected to provide socially optimal managerial incentives.

\section{Evasion}

Evasion strategies are an obvious threat to a double liability regime. In the corporate tort debate, Joseph Grundfest claimed that an unlimited liability regime is unlikely to work because capital markets will generate large pools of non-assessable shareholders. ${ }^{91}$ The same claim applies to a regime of double liability. One of Grundfest's main proposed evasion schemes is an effort by market intermediaries to create specialised holding structures (or investment funds) to separate returns on equity from the risk of paying excess tort damages under a proportionate liability rule. Such a fund would hold no assets except stock in a single risky firm. In addition, it would issue no equity itself that might absorb the personal liability attaching to its investment shares. Investors in the fund could therefore hope to divide the returns from risky equity free of the danger of double liability. ${ }^{92}$ As Hansmann and Kraakman, who argue in favour of a regime of unlimited liability for corporate torts, respond, no court would accept such a fund at face value because its sole function would be to

\footnotetext{
${ }^{89}$ See, Basel Comm. on Banking Supervision, Enhancements to the Basel II Framework (2009) 26, which requires the involvement of expert, independent directors in the design and operation of banks' compensation policies.

${ }^{90}$ Lucian Bebchuk and Holger Spamann, 'Regulating Bankers' Pay' (2009) Harvard Law School John M. Olin Center for Law, Economics and Business Discussion Paper Series. Paper 634, 36.

${ }^{91}$ Joseph Grundfest, 'The Limited Future of Unlimited Liability: A Capital Markets Perspective' (1992) 102 Yale Journal on Regulation 387.

92 ibid.
} 
evade liability. In the event of failure, a court would-or at least shouldassign the full liability of the fund's equity holdings to its investors. ${ }^{93}$

Similarly, the court should have little difficulty identifying an opportunistic recapitalisation in which, to avoid liability, an issuer shrinks its traditional equity base to a small pool of attachment-proof shareholders while employing equity substitutes and debt to serve the risk bearing and control functions normally served by common stock. Confronted with such a blatant evasion tactic, a court need only re-characterise the equity substitutes as constructive equity for purposes of, in this case, double liability. ${ }^{94}$

Small domestic shareholders, Grundfest argues, are likely to escape damage assessments under a proportionate liability rule because they will owe too little to justify the costs of collecting from them. ${ }^{95}$ Taking inspiration from one of the recommendations from Hansmann and Kraakman: federal legislation could shift the legal costs of collecting on a valid double liability debt to shareholders and deter even the smallest shareholder from ignoring a judgment. ${ }^{96}$

The evasion efforts considered here are not intended to be exhaustive. I do not dispute that evasion efforts represent real problems for double liability. If bank shareholders are themselves limited liability entities, then any effort to collect more than the equity investment is immediately thwarted. ${ }^{97}$ For this reason, I support giving courts the authority to declare any efforts to evade double liability with the corporate form invalid. This paper also emphasises that the case studies cited above on recovery under double liability provides reassurance as to the feasibility of such a regime and therefore suggests evasion-based objections are not insurmountable.

\footnotetext{
${ }^{93}$ Henry Hansmann and Reinier Kraakman, 'Do the Capital Markets Compel Limited Liability? A response to Professor Grundfest' (1992) 102 Yale Journal on Regulation 427, 431.

94 ibid, 430.

${ }^{95}$ Joseph Grundfest, 'The Limited Future of Unlimited Liability: A Capital Markets Perspective' (1992) 102 Yale Journal on Regulation 387.

${ }^{96}$ Henry Hansmann and Reinier Kraakman, 'Do the Capital Markets Compel Limited Liability? A response to Professor Grundfest' (1992) 102 Yale Journal on Regulation 427, 432.

97 Peter Conti-Brown, 'Solving the Problem of Bailouts: A Theory of Elective Shareholder Liability' (2011) Rock Center for Corporate Governance Working Paper Series No.97, 23.
} 


\section{Costs of equity}

Another argument supporting the retention of the current limited liability regime is an equity costs issue. It might be suggested that under double liability, the cost of equity would increase to an inappropriately high level, since banks are subject to capital requirements this could problematic. As a result, investors may be discouraged from investing in banks. Two points can be made in this regard. First, under the previous double liability regime, this appears not to have been a source of great concern-banks still attracted investors. However, as indicated earlier when double liability previously operated the structure of shareholding was concentrated. Diversified shareholders might think the costs of monitoring are not worth the returns. Second, as Peter Conti-Brown, an advocate for elective shareholder liability, convincingly argues, the cost of equity would merely be raised to an efficient level to reflect and internalise risk. ${ }^{98}$ Thus, from a market efficiency perspective, this could be seen as beneficial. At present, this is a speculative concern since there is insufficient evidence to indicate to what extent the cost of equity would increase and the extent to which investors would be discouraged. Before either the concern or the case for double liability is defeated, more evidence is required.

\section{Double liability: a complementary policy}

Double bank shareholder liability can be viewed as complimentary to two existing policy approaches. The first approach, exemplified by the DoddFrank Wall Street Reform and Consumer Protection Act of 2010, seeks to end government bailouts. ${ }^{99}$ As pointed out by Lawrence Summers, a healthy financial system cannot be built on the expectation of bailouts. ${ }^{100}$ The second, as described in section II.G, is the targeted approach of making remuneration arrangements sensitive to risk, an approach which

98 Peter Conti-Brown, 'Solving the Problem of Bailouts: A Theory of Elective Shareholder Liability' (2011) Rock Center for Corporate Governance Working Paper Series No.97, 55.

${ }^{99}$ Additionally, § 214(c) prohibits taxpayer funding. For academic support on this move, see, Kenneth Scott, George Shultz and John Taylor, Ending Government Bailouts As We Know Them, (Hoover Institution Press 2009). See also, David Skeel, The New Financial Deal: Understanding the Dodd-Frank Act and its (Unintended) Consequences, (John Wiley \& Sons 2011).

${ }^{100}$ Lawrence Summers, 'International Financial Crises: Causes, Prevention, and Cures' (2000) 90(2) American Economic Review 1, 13. 
this paper also supports. It is stressed that reform should not come down to a choice between such measures or double liability. Indeed, the analysis in section II.F has indicated that there are two problems present. Consequently, it is argued that both measures can be complimentary to one another. It might, however, be suggested that further proposals such as those advocated by Patrick Bolton et al, basing compensation on both stock price and the price of debt (proxied by the CDS spread) ${ }^{101}$ or, Jeffrey Gordon, convertible equity-based pay, are preferable. ${ }^{102}$ The argument may be that such measures go more directly to the problem than double liability because if managerial compensation arrangements are adequately risk sensitive, the space open for excessive risk-taking would be limited. Even if it is accepted that bank risk-taking is shareholder push rather than managerial pull, it could further be argued that under these measures shareholders' ability to pressure management to accept greater risk might also be limited. The thinking here is that the main mechanism that exposes managers to shareholder pressure - the design of pay arrangements-would be considerably weakened since shareholders would no longer have a free hand in designing such arrangements. However, this brings back into focus an earlier point-that is, bank shareholders have other means by which to pressure and incentivise their management to accept greater risk. The alternative mechanism brought to light in this paper is the threat of removal. As argued in section II.F, a manager's survival in office relies on the maximisation of shareholder value. If managers, as a result of risk-sensitive pay arrangements, reject risky projects that increase the share price, bank shareholders could threaten to remove them from office. Shareholders could therefore continue to pressure their management to accept greater risk through the threat of removal. Managers, standing to lose their human capital, private benefits of control, financial capital, and have their reputation negatively affected by removal, could be highly incentivised to comply. Viewed in this light, such measures cannot be relied on to completely mitigate bank shareholders' push towards excessive risk-taking. Double liability targets another aspect of the problem by making bank shareholders more risk

\footnotetext{
${ }^{101}$ Patrick Bolton, Hamid Mehran and Joel Shapiro, 'Executive Compensation and Risk Taking' (2011) Federal Reserve Bank of New York Research Paper Series Staff Report No.456.

102 Jeffrey Gordon, 'Executive Compensation and Corporate Governance in Financial Firms: The Case for Convertible Equity-Based Pay' Columbia Law School and European Corporate Governance Institute Working Paper No. 373 (2010).
} 
averse, and can, as a result, be thought of as a complimentary policy that bridges the gap in the response to make less likely, excessive risk-taking.

Finally, double liability could also have direct implications for managers. The reason for this is that if equity continues to account for a large proportion of managerial compensation, which the stimulus bill indicates will be the case, ${ }^{103}$ then managers required to retain stock would also be liable in the event of bank failure, for an amount up to, but not exceeding, the par value of their stock in the bank. This could produce a similar incentive for managers to reduce their appetite for risk.

\section{E. CONCLUSION}

This paper has argued that excessive risk-taking is also partly a product of the conventional model. It has identified some key factors that have provided bank shareholders with incentives to pressure management to accept greater risk. Current corporate governance reforms have been shown to be incapable of addressing the problem identified. To reduce bank shareholders' risk appetite, the paper has modified the conventional model to include a plausible alternative approach-a regime of double liability. The characteristics and policy advantages of double liability have been explored, with the aid of empirical evidence. Possible objections for the regime have been recognised, and in responding to such objections, it has been suggested that they are not insurmountable-the costs of equity issue remains unresolved. Of course, there may be arguments that could defeat the case for double bank shareholder liability. However, they have yet to be introduced into the debate. It is hoped that this paper sparks renewed interest in the regime, as the burden is now shifted on the proponents of the existing model and current limited liability regime to provide a persuasive case for their continued existence in banks.

The thesis presented in this paper may be hard to swallow. The conventional model is deeply rooted in corporate governance, while the current rule of limited liability has also gained a status of orthodoxy. However, until the problem identified is both acknowledged and

10312 U.S.C. $\$ 5221(\mathrm{~b})(3)(\mathrm{D})(\mathrm{i})$ (2009) (codifying the EESA and incorporating amendments pursuant to the American Recovery and Reinvestment Act of 2009). This requires that incentive compensation for top officers and employees of TARP recipients be exclusively in long-term restricted common stock. 
addressed, excessive risk-taking cannot be expected to be significantly reduced by corporate governance. 